\title{
"The choice of public universities in a restructured and transforming Higher Education landscape: a student perspective"
}

\begin{tabular}{ll} 
AUTHORS & $\begin{array}{l}\text { Soobramoney Penceliah } \\
\text { Samkele V.M. Konyana } \\
\text { Mandusha Maharaj }\end{array}$ \\
& $\begin{array}{l}\text { Soobramoney Penceliah, Samkele V.M. Konyana and Mandusha Maharaj } \\
(2016) . \text { The choice of public universities in a restructured and transforming }\end{array}$ \\
ARTICLE INFO & $\begin{array}{l}\text { Higher Education landscape: a student perspective. Problems and Perspectives } \\
\text { in Management, } 14(3-1), 276-282 . \text { doi:10.21511/ppm.14(3-1).2016.14 }\end{array}$ \\
\hline DOI & http://dx.doi.org/10.21511/ppm.14(3-1).2016.14 \\
\hline RELEASED ON & Tuesday, 06 September 2016 \\
\hline JOURNAL & "Problems and Perspectives in Management" \\
\hline FOUNDER & LLC "Consulting Publishing Company "Business Perspectives"
\end{tabular}

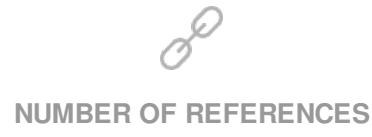

0

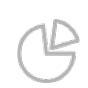

NUMBER OF FIGURES

0

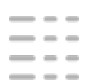

NUMBER OF TABLES

0

(C) The author(s) 2022. This publication is an open access article. 

(South Africa)

\title{
The choice of public universities in a restructured and transforming Higher Education landscape: a student perspective
}

\begin{abstract}
The central tenet of the new Constitution of South Africa is to create equal and socially just economic order. This resulted in the higher education sector being restructured through incorporations and mergers. The limited financial resources, forces universities to evaluate and review their marketing strategies in order to attract suitably prepared and qualified students. The universities have not fully explored the role played by choice factors in influencing the students' decision of enrolling at a particular university.

The purpose of this study is to identify the factors that may influence students in their choice of selecting a public university in the Tshwane Metropolitan Region, South Africa. An empirical study was conducted amongst first year students at two public universities in the Tshwane Metropolitan Region, Pretoria. The study design was quantitative in nature, using a descriptive technique, cross sectional and collected data through the application of a non-probability sampling being utilized to obtain data from a sample of 216 respondents.

The results of this study suggest that South African education landscape has evolved towards a market-orientated system in which Higher Education Institutions operate as businesses with marketing challenges. The results provide HEIs a guide to identify the key factors that influence students in the selection of a university in a developing country. University management should take cognizance of the gaps and position the university as an institution of first choice in South Africa.
\end{abstract}

Keywords: demographics, choice factors, universities, higher education institutions (HEIs).

JEL Classification: M31, L14, L31.

\section{Introduction}

The rationale for this study evolved from a political interest, in terms of addressing the imbalances of the past in the South African higher education sector. The Higher Education Institutions (HEIs) are expected to determine how current and prospective students make their decisions, identify the factors they consider, how students weigh relative value of the factors and the influences that operate in the process. Previous studies identified factors that students consider in their choice of a university. The important factors include academic reputation, location, and quality of education, availability of programs, and quality of the faculty, cost, reputable programs, financial aid and job outcomes. The other factors are variety of courses offered, size of institution, admission requirements surrounding community, quality of social life, class size, extracurricular programs, and attractiveness of campus facilities, friendly/personal service, and admission to graduate school. The South African government aims to achieve equitable access to higher education for previously underprivileged students with different educational backgrounds (Hardman and Ng'ambi, 2003). According to van der Merwe (2004), the shift from predominately White elite higher education system to a mass education system means

(C) Soobramoney Penceliah, Samkele V.M. Konyana, Mandusha Maharaj, 2016.

Soobramoney Penceliah, Adjunct Professor of Marketing, Department of Marketing \& Retail Management, Durban University of Technology, South Africa.

Samkele V.M. Konyana, Student of Marketing, Department of Marketing \& Retail Management, Durban University of Technology, South Africa.

Mandusha Maharaj, Senior Lecturer in Marketing, Department of Marketing

\& Retail Management, Durban University of Technology, South Africa. major changes in the composition of student population. Universities promotional strategies require incorporating influential factors that students may consider when choosing the higher education institution to enrol at.

According to Jones (2002), consumers are mostly influenced by cultural, social, personal, and psychological characteristics. Hoyte and Brown (2003) utilized twenty-two previous studies to identify factors considered by students when choosing a higher education institution. The authors identify the following factors, academic reputation, location, and quality of education, availability of programs, quality of the faculty, cost, reputable programs, financial aid and job outcomes. The other important factors are variety of courses offered, size of the institution, admission requirements surrounding community, quality of social life, class size, extracurricular programs, attractiveness of campus facilities, friendly/personal service, and admission to graduate school.

A South African study by Cosser and Du Toit (2002) found that reputation of the institution or study program has the most influence for the choice of the institution. The study also indicates that the provision of world class sporting facilities have a greater influence on choice than scholarships, paternal study, fees or friends' recommendation. A study by Bonemma (2006) also identifies sport, study programs, student life and money as important factors that students consider when selecting an institution. Results obtained by the study conducted by Jones (2002) show 
family, career exhibitions and friends as important factors that students consider when selecting a higher education institution. The outcome of this study is to identify the factors that influence students' choice of a public university in a restructured and transforming higher education landscape.

\section{Literature review}

1.1. Higher education institution (HEI) landscape. The landscape of South African higher education has been going through major restructuring since 1994, influenced by policy development which includes the following: National Commission on Higher Education Report (NHCE 1) (South Africa, 1997), National Plan for Higher Education (NPHE, 2001), Education White Paper (EWP, 1997) and the Council on Higher Education Report (South Africa, 2008). The National Plan for Higher Education provides a framework for the restructuring of the higher education system to achieve the goals for transformation in the higher education system as outlined in the White Paper (Transformation of higher education, 1997). Technikons were transformed to Universities of Technology and some higher education institutions were merged. Furthermore, the landscape of higher education was also aimed at promoting the sharing of resources including academic staff and library resources, eliminating duplication and promoting synergies between disciplines, universities and communities (Council on Higher Education size and shape Task Team, 2000). Due to these changes, HEIs are confronted with competition, decrease in government funding, an increase in marketing costs, and non-payment of student fees. The restricted financial resources require HEIs to re-evaluate their marketing and recruitment strategies so that the desired students are attracted.

The higher education system in South Africa is moderated and valued by the extent to which it provides greater access and opportunity for a selected group, especially Black African, Coloured, South African women and other socially disadvantaged groups (Council on Higher Education size and shape task team, 2000). According to Pityana (2004), the universities are expected to open doors of learning to all races, in order to develop a student body that more accurately reflects South Africa's demographic profile and transform campuses and cultures to become less isolating to students from various backgrounds.

1.2. Choice factors. There are many choice factors that prospective students may use in their decision making process to select an institution. Factors such as sporting, accessibility, comfortable attractive environments, employment prospects, course content aspects, financial aspects and the feel of the institution also play a crucial role in the decision making process (Bonnema and Van der Waldt, 2008). Sevier (1993) suggests that higher education institutions must understand the factors that influence the selection process of prospective students.

The importance attached to each criterion varies from one student to the other. Some choice factors are more important than the others, depending on the prospective student perception of what is important and what is not. A study done by Jones (2002) ranks choice factors, amongst others as: course, financial aid, status and reputation of institution, academic requirements, language, fees, travelling, in-service training, parents, pass rate and sporting facilities. In his study, Mills (2004) shows that the majority of students attached a high level of importance to financial aid offered by the higher education institution. Furthermore, in a study by Hoyt and Brown (2003), students with great academic potential attached a higher level importance to academic reputation, quality and scholarships than the academically challenged students. Black and Hispanic students were more concerned about the cost of education; therefore, financial assistance was a crucial choice factor to them.

A study by Hoyt and Brown (2003) shows that mature students, compared to younger counterparts attach greater importance to choice factors, such as flexible study times, and job opportunities. Demographics have many areas of diversity including: age, gender, national origin, race, religion and sexual orientation. Most students' motivation to enrol at higher education institutions is influenced by their belief that it is the gateway to employment (Cosser and du Toit, 2001). Some students will be concerned with esteem needs when they enrol at the higher education institution. Jones (2002) mentions that the historically black institutions that served the underprivileged students in the past are often seen as being low-grade because of the student market they have served and the financial status of the institution.

Societies can be divided into subcultures that are made up of people who are similar in terms of their ethnic origin, customs and the way they behave, such as race, language spoken and religion (Hawkins et al., 2004). A study by Cosser and Du Toit (2002) established that racial/ethnic groups are influenced by different choice factors when it comes to selecting a higher education institution. Cosser and Du Toit (2002) found that South African students see higher education as a gateway to employment and the main reason to enrol at a higher education institution. Students from high social class have advantages of obtaining all sorts of information they need about a higher education institution. Students from low social positions struggle to obtain information such as student loan brochures and criteria of selecting a higher education institution (Jones, 2002). Martin and 
Bush (2000) found that role models have an important effect on the career aspirations and educational choices of young adults. Family also provides helpful channels for information concerning higher education. Cabrera and Steven (2000) regard parental encouragement as one of the powerful factors. The family's levels of education plays a role in influencing the child's education. Kotler and Armstrong (2013) identify the following sources that the student as a consumer engages in the search for information:

- personal, includes family, friends and others;

- commercial, includes promotion, sales personnel and websites; and

- experiential, includes the experience of other students.

The next section discusses the research methodology that was employed for this study.

\section{Methodology}

This study used the survey methodology approach to collect data and the design had a descriptive focus. The study is a cross sectional study, as participants were surveyed on one occasion.

The study focused at two public higher education institutions in the Tshwane metropolitan, namely: Tshwane University of Technology and the University of Pretoria. Though, the target population was first year students in the faculty of Science, Engineering, and Management Sciences, the study did not consider the field of study as a factor of choice.

For the purpose of this study, data were collected using a questionnaire modified from Wiese (2008) to investigate the factors that influence the decision making process of students' when choosing an institution for enrolment.
Data obtained from the questionnaire were represented in charts, figures and tables. Cross tabulations were used to assess the relationship between variables and factor analysis was also used to identify major factors in the research questions. Other relevant statistical tests, such as inferential statistical analysis, were used to test the research objectives.

2.1. Results and discussion. The mean scores were used to rank the factors that influence students' choice of a public university.

2.1.1. Ranking choice factors. Ten of the most important factors that the students consider when choosing a higher education institution and the findings were compared to the results of similar previous studies. In this study, the following factors were identified in terms of mean scores (1-5): the quality of teaching was rated (1), availability of financial assistance was rated at number (2), and ease of finding employment during and after the study was rated at (3), qualifications recognized worldwide (4) and sport and recreation programs (5), on campus housing/hostels.

Least considered factors during a consumer decision making process: (6), wide variety of courses /programs offered (7), campus life/atmosphere (8), language policy (9), and flexible study mode (evening classes, use of computers) (10), good image of the university (11), campus safety and security (12), academic reputation (prestige) (13), links with the industry (14), location of the institution (15), multi-cultural/diversity, (16), and parents/siblings attended this institution (tradition) (17).

Table 1 highlights the factors students consider when choosing a university.

Table 1. Factors students considered in their decision making

\begin{tabular}{|c|c|c|c|c|c|c|c|c|c|c|c|c|}
\hline \multirow{2}{*}{ Dimension } & \multirow{2}{*}{ Rank } & \multirow{2}{*}{ Mean } & \multicolumn{2}{|c|}{ Not important at all } & \multicolumn{2}{|c|}{ Of little important } & \multicolumn{2}{|c|}{ Uncertain } & \multicolumn{2}{|c|}{ Important } & \multicolumn{2}{|c|}{ Very important } \\
\hline & & & $\mathrm{N}$ & $\%$ & $\mathrm{~N}$ & $\%$ & $\mathrm{~N}$ & $\%$ & $\mathrm{~N}$ & $\%$ & $\mathrm{~N}$ & $\%$ \\
\hline Qualifications recognized worldwide & 4 & 3.56 & 58 & 26.9 & 7 & 3.2 & 6 & 2.8 & 46 & 21.3 & 99 & 45.8 \\
\hline Location of the institution & 15 & 2.75 & 101 & 46.8 & 7 & 3.2 & 10 & 4.6 & 48 & 21.3 & 50 & 23.1 \\
\hline Ease of finding employment during and after the study & 3 & 3.59 & 107 & 26.5 & 109 & 27.4 & 10 & 4.6 & 28 & 13.0 & 62 & 28.7 \\
\hline Wide variety of courses / programs offered & 7 & 3.00 & 90 & 41.7 & 3 & 1.4 & 6 & 2.8 & 50 & 23.1 & 67 & 31.0 \\
\hline Academic reputation (prestige) & 13 & 2.81 & 59 & 26.9 & 57 & 26.7 & 14 & 6.5 & 37 & 17.1 & 49 & 22.7 \\
\hline Parents/siblings attended this institution (tradition) & 17 & 2.13 & 86 & 39.5 & 76 & 35.5 & 14 & 6.5 & 21 & 9.7 & 19 & 8.8 \\
\hline Good image of the university & 11 & 2.87 & 55 & 25.7 & 52 & 24.7 & 14 & 6.5 & 47 & 21.8 & 46 & 21.3 \\
\hline Language policy & 9 & 2.93 & 56 & 25.7 & 51 & 23.9 & 14 & 6.5 & 37 & 17.1 & 58 & 26.9 \\
\hline Financial assistance (bursary \& loans) & 2 & 3.66 & 53 & 24.6 & 8 & 3.7 & 10 & 4.6 & 34 & 15.7 & 111 & 51.4 \\
\hline Quality of teaching & 1 & 3.86 & 74 & 34.1 & 63 & 29.0 & 14 & 6.5 & 34 & 15.7 & 91 & 42.1 \\
\hline Campus safety and security & 12 & 2.83 & 57 & 27.1 & 58 & 27.6 & 10 & 4.6 & 31 & 14.4 & 57 & 26.4 \\
\hline Multi-cultural/ diversity & 16 & 2.60 & 62 & 28.7 & 64 & 29.6 & 16 & 7.4 & 46 & 21.3 & 28 & 13.0 \\
\hline Flexible study mode (evening classes, use of computers) & 10 & 2.87 & 59 & 27.5 & 60 & 27.6 & 8 & 3.7 & 29 & 13.4 & 60 & 27.8 \\
\hline On campus housing/ hostels & 6 & 3.01 & 46 & 21.3 & 66 & 30.6 & 6 & 2.8 & 35 & 16.2 & 63 & 29.2 \\
\hline Sport and recreation programs & 5 & 3.24 & 48 & 22.0 & 44 & 20.6 & 9 & 4.2 & 39 & 18.1 & 76 & 35.2 \\
\hline Campus life/ atmosphere & 8 & 2.99 & 52 & 24.3 & 54 & 24.8 & 11 & 5.1 & 43 & 19.9 & 56 & 25.9 \\
\hline Links with the industry & 14 & 2.81 & 58 & 26.9 & 57 & 26.4 & 16 & 7.4 & 39 & 18.1 & 46 & 21.3 \\
\hline
\end{tabular}


Both studies by Wiese (2008) and Wiese, van Heerden, Jordaan and North (2009) reveal that the quality of teaching was rated (1) as the most influential factor, followed by employment prospects (2), campus safety and security (3), academic facilities (4), and international links (5).

In the study by Redmond (2010), the influential factors were rated as follows: standard of education provided (1), programs offered (2), likely employment once graduated (3), location (4), and work integrated learning (5).

Quality of teaching received a highest mean score 3.86 which means there is a high agreement within respondents on this factor. The findings of Ivy's (2001) local study are supported by the findings in this study, as quality of teaching, variety of courses, and availability of bursaries received mean values between 3.00-3.86. With regards to Ivy's UK study, the results of this study also indicate an agreement on this factor as quality of teaching also received a high mean score of 3.86 .

An international study by Petruzel and Romannazzi (2010) identify emotional value, price/quality, social value, and functional value as the effective choice factors that students consider in their decision making. The results of this research study also agree with the previous studies by Bonnema (2006), Wiese (2008), Wiese et al. (2009) and Redmond (2010) that respondents are consistent in terms of how they view the importance of quality of teaching and employment prospects, although in terms of being rated in order of importance, the factors received a different scaling.

Financial assistance is rated the second best factor with $67.1 \%$ of respondents indicated that financial assistance is the second influencing factor. In Wiese's (2008) study, fees were ranked at thirteenth place with a high mean score of 3.7 , which is similar to a mean score of 3.66 that was obtained in this study. This finding indicates that there may be a large number of students from previously disadvantaged backgrounds who enrol at these institutions. Jones' (2002) study also revealed that students consider financial assistance in their decision making. The quality of teaching, and academic recognition, the findings of Ivy's (2001) study prove to be similar. There is a contradiction when it comes to financial assistance, as international higher education institutions indicate that they do not consider the availability of bursaries and other choice factors during their decision making process.

With regard to ease of finding employment, findings indicate that students are concerned about their future especially after completing their studies. This concern may arise from the need to improve lifestyles and receive a return in investment. The study by Bonemma
(2006) identifies employability, course content, student life, sport and money as important information needs that students consider when selecting an institution.

Worldwide recognition of academic qualification was rated as the third most influential factor. With regards to Ivy's (2001) UK study, the results of the study indicate an agreement on qualifications recognized worldwide. This urge of qualifications being recognized worldwide may arise from the fact that respondents may later on in life have ambitions to further their studies in other countries. Therefore, when the interest to further their studies arises, the respondents would like the current qualifications to be able to open doors and opportunities for them at any higher education institution across the world.

The results show that sport and recreation programs were rated fifth in the top ten of the considered factors. A study by Coetzee and Liebenberg (2004) noted that reputation, image, sporting facilities, friends attending the same institution, and the location of the institution were regarded as the most influential factors. However, the results of this study are only in agreement with one factor (sport and recreation programs). Other previous findings by Cosser and $\mathrm{Du}$ Toit (2002) and Bonnema (2006) also recognize the importance of sport and recreation facilities.

On-campus housing was rated the sixth most influential factor in the decision making process with a mean value of 3.01. However, this factor should also be considered to be very important, as the findings show that $64.4 \%$ of the respondents came outside of Gauteng Province (Pretoria). The above mentioned finding could be the reason that on-campus housing was rated in the top 10 of the most influential factors during the decision making process.

Word of mouth was rated as the last influencing factor during the decision making process. The findings of the study may be an indication that the respondents know what they want or that they do not want family to influence major decisions in their lives. Most of the above mentioned studies reveal a significant agreement that reference groups (family, friends) exerted little influence when it comes to the decision making. In international study by Haikins (2006), respondents indicated that they preferred personal opinions from friends, family or work colleagues and this is contrary to the findings of this study and other local studies, as the results indicate that this factor was rated as the least considered factor during the decision making process. Only findings by Jones (2002) show that $75.7 \%$ of respondents indicated that the family had influenced their decision to study at a particular institution.

2.1.2. Demographic profile of students. The Chisquare test measured the level of significance 
( $p$-value between $<0.05$ and 0.01 ). Table 2 depicts the relationship between the demographic profile of students and factors student consider when selecting a university.

The following statistical significant relationships were identified as factors students consider when choosing a university.

There is a significant relationship between gender and employment opportunities at $1 \%$ level off significance and under variety of programs offered at the HEI's at $5 \%$ level of significance, respectively. It is, therefore, apparent that the respondents attach a very high level of importance to employment opportunities and variety of programs offered by higher education institutions in the decision making process.

A significant relationship exists between the province of origin and campus housing at $1 \%$ level of significance and with regard to language policy at 5\% level of significance. Majority of respondents came outside the Gauteng Province and did not speak English or Afrikaans. Hence, there is a significant relationship between province of origin and language policy and campus housing.
It was also observed that a significant relationship exists between the respondents' home language and financial assistance, on campus housing and cultural diversity at 5\% level of significance. Majority of respondents speak South African indigenous languages and, therefore, it may be concluded that within this group financial assistance, on campus housing and cultural diversity play a critical role in the students' selection of universities in Pretoria.

There is a significant relationship between the respondents' current education institution and parents attending the same institution and on campus housing at the $1 \%$ level of significance. Furthermore, the current institution of study and selection dimensions (language policy, financial assistance and links with the industry) reported a relationship at 5\% level of significance, respectively.

There is a significant relationship between the respondents' field of study and worldwide recognition of qualifications at the $1 \%$ level of significance and the parents' tradition at $5 \%$ level of significance.

Table 2. Chi-square test of demographics and factors students consider when selecting a university

\begin{tabular}{|l|c|c|c|c|c|}
\hline \multicolumn{1}{|c|}{ Dimension } & Gender & $\begin{array}{c}\text { Which province do } \\
\text { you come from? }\end{array}$ & $\begin{array}{c}\text { What is your home } \\
\text { language? }\end{array}$ & $\begin{array}{c}\text { Which institution are you } \\
\text { currently studying at? }\end{array}$ & $\begin{array}{c}\text { Which field of study } \\
\text { are you currently in? }\end{array}$ \\
\hline Qualifications recognized worldwide & 0.141 & 0.812 & 0.746 & 0.083 & $0.012^{*}$ \\
\hline Location of the institution & 0.716 & 0.385 & 0.586 & 0.362 & 0.159 \\
\hline Ease of finding employment during and after the study & $\mathbf{0 . 0 0 6 ^ { * }}$ & 0.701 & 0.203 & 0.512 & 0.885 \\
\hline Wide variety of courses / programs offered & $\mathbf{0 . 0 1 7 ^ { * }}$ & 0.773 & 0.636 & 0.09 & 0.091 \\
\hline Academic reputation (prestige) & 0.565 & 0.978 & 0.614 & 0.398 & 0.263 \\
\hline Parents/siblings attended this institution (tradition) & 0.163 & 0.409 & 0.366 & $0.000^{*}$ & $0.045^{\star}$ \\
\hline Good image of the university & 0.435 & 0.466 & 0.172 & 0.817 & 0.376 \\
\hline Language policy & 0.633 & $0.006^{*}$ & 0.179 & $0.041^{*}$ & 0.835 \\
\hline Financial assistance (bursary \& loans) & 0.5 & 0.97 & $0.033^{*}$ & $0.042^{*}$ & 0.125 \\
\hline Quality of teaching & 0.107 & 0.62 & 0.302 & 0.585 & 0.096 \\
\hline Campus safety and security & 0.124 & 0.948 & 0.291 & 0.853 & 0.681 \\
\hline Multi-cultural/ diversity & 0.791 & 0.726 & 0.025 & 0.373 & 0.722 \\
\hline Flexible study mode (evening classes, use of computers) & 0.583 & 0.706 & 0.601 & 0.713 & 0.757 \\
\hline On campus housing/ hostels & 0.423 & $\mathbf{0 . 0 3 6}$ & $\mathbf{0 . 0 2 1 ^ { * }}$ & $\mathbf{0 . 0 1 0 ^ { * }}$ & 0.153 \\
\hline Sport and recreation programs & 0.339 & 0.457 & 0.862 & 0.707 & 0.846 \\
\hline Campus life/ atmosphere & 0.281 & 0.974 & 0.673 & 0.797 & 0.857 \\
\hline Links with the industry & 0.308 & 0.527 & 0.212 & $\mathbf{0 . 0 2 0 ^ { * }}$ & 0.213 \\
\hline
\end{tabular}

2.2. Major categories of choice factors. The study also reduced the seventeen choice factors used by students into five major categories. Table 3 depicts seventeen variables that students consider in the choice of HEI's. The rotated component matrix test reduced the seventeen factors considered by students in the decision process into five main factors. A value of greater than 0.5 was selected as a cut-off point.

Table 3. The rotated component matrix of factors considered

\begin{tabular}{|l|c|c|c|c|c|}
\hline \multicolumn{1}{|c|}{$\begin{array}{c}\text { Factors students' consider in their decision making when choosing a higher education } \\
\text { institution (HEI) }\end{array}$} & 1 & 2 & 3 & 4 & 5 \\
\cline { 2 - 6 } & 0.009 & -0.054 & -0.040 & -0.085 & $\mathbf{0 . 7 5 2}$ \\
\hline Qualifications recognized world wide & 0.492 & -0.226 & 0.033 & $\mathbf{0 . 5 0 6}$ & -0.312 \\
\hline Location of the institution & 0.091 & 0.177 & 0.055 & $\mathbf{0 . 5 8 4}$ & $\mathbf{0 . 5 5 3}$ \\
\hline Ease of finding employment during and after the study & 0.307 & -0.106 & 0.293 & 0.482 & 0.208 \\
\hline Wide variety of courses / programs offered & &
\end{tabular}


Table 3 (cont.). The rotated component matrix of factors considered

\begin{tabular}{|l|c|c|c|c|c|}
\hline \multicolumn{1}{|c|}{$\begin{array}{c}\text { Factors students' consider in their decision making when choosing a higher education } \\
\text { institution (HEI) }\end{array}$} & \multicolumn{4}{c|}{ Component } \\
\cline { 2 - 6 } & 1 & 2 & 3 & 4 & 5 \\
\hline Academic reputation (prestige) & -0.020 & 0.185 & 0.109 & $\mathbf{0 . 8 1 0}$ & -0.107 \\
\hline Parents/siblings attended this institution (tradition) & -0.212 & -0.263 & $\mathbf{0 . 6 4 3}$ & 0.067 & 0.202 \\
\hline Good image of the university & 0.199 & 0.102 & $\mathbf{0 . 5 1 2}$ & 0.474 & -0.015 \\
\hline Language policy & -0.140 & $\mathbf{0 . 7 5 9}$ & 0.022 & -0.052 & -0.125 \\
\hline Financial assistance (bursary \& loans) & $\mathbf{0 . 5 9 0}$ & $\mathbf{0 . 5 3 5}$ & 0.203 & -0.096 & -0.040 \\
\hline Quality of teaching & 0.320 & $\mathbf{0 . 5 5 2}$ & -0.037 & 0.165 & $\mathbf{0 . 5 0 5}$ \\
\hline Campus safety and security & 0.080 & $\mathbf{0 . 8 1 9}$ & 0.134 & 0.184 & 0.211 \\
\hline Multi-cultural/diversity & 0.114 & 0.180 & $\mathbf{0 . 7 5 2}$ & 0.066 & 0.047 \\
\hline Flexible study mode (evening classes, use of computers) & 0.136 & 0.248 & $\mathbf{0 . 6 3 5}$ & 0.044 & -0.339 \\
\hline On campus housing/hostels & 0.461 & 0.276 & 0.325 & $0-.498$ & -0.107 \\
\hline Sport and recreation programs & $\mathbf{0 . 7 9 8}$ & -0.017 & -0.135 & 0.124 & 0.094 \\
\hline Campus life/atmosphere & $\mathbf{0 . 6 0 7}$ & -0.060 & 0.395 & 0.143 & 0.330 \\
\hline Links with the industry & 0.427 & 0.217 & 0.290 & 0.042 & 0.474 \\
\hline
\end{tabular}

Factor 1: was identified as psychographic segmentation factors (financial assistance, sport and recreation programs and campus life).

Factor 2: was identified as institutional/situational factors. The three factors: language policy, quality of teaching, and campus safety were grouped into one category by respondents.

Factor 3: the four factors: tradition, image, cultural diversity, and flexible study mode were identified as external factors influencing consumer decisionmaking process.

Factor 4: was identified as career development incentives (locations of the institution, job opportunities, image of the institution).

Factor 5: was identified as career advancing factors (worldwide recognition of academic qualification and ease of finding employment) influencing the consumer decision making with specific reference to choice of HEIs in Pretoria.

The findings of this study show that respondents were concerned with the core product and had certain expectations of the product and were also concerned with the augmented aspects of the product. The importance of the core product was rated in the first five factors that students consider in the decision making process. Two important factors (quality of teaching and financial assistance) that are features of the expected product were identified in the first five of the most important factors considered by students. Ease of finding employment, sport and recreation programs were also rated in the first five of the most considered factors which show that students were also interested in the product augmented characteristics. The results indicate that product image did not play a role in influencing the respondents' choice. Future studies should include the field of study as a factor influencing the choice of public universities, as literature suggests that business and engineering students priorities towards university selection are different.

\section{Conclusions and recommendations}

The results suggest that the South African education landscape has evolved rapidly towards a marketorientated system in which HEIs operate as businesses with marketing challenges. This study has shown that higher education marketers must develop a decision making model that takes into consideration the identified choice factors. This study and other recent studies (Redmond, 2010) indicate a vast difference on the importance students attach to choice factors.

Higher education institutions need to form strategic alliances with both public and private sector in order to address the respondents' concern about finding employment after qualification and also the availability of financial assistance, as the results indicate that it is a worrying factor for a majority of respondents. The results of this study and previous studies (Bonnema, 2006 and Coetzee and Liebenberg, 2004) also suggest that there is a need to investigate the role played by the availability of sport and recreation programs and facilities in the decision making process.

Higher education institutions should develop a marketing strategy that integrates the most considered choice factors that influence choice of a university. They should aim at segmenting its markets in order to determine needs and wants of groups that may exist within the target market. Higher education institutions may need to consider geographical market segmentation to identify the needs of the diverse target market. They must understand governments' requirements of diversity and inclusion of students from previously disadvantaged backgrounds and also understand the demographics of the target market, as prescribed by governments' policies. 


\section{References}

1. Bonnema, J. (2006). Information needs and source preference of prospective learners at tertiary Institutions: an integrated marketing communication approach. Bachelor's Degree thesis, University of Pretoria.

2. Bonnema, J. and van der Waldt, D.L.R. (2008). Information needs and source preference of a student market in higher education, International journal of educational management, 22 (4), pp. 314-327.

3. Coetzee, M.D. and Liebenberg, E. (2004). The influence of corporate reputation on the choice of the University of Pretoria as a preferred higher education institution: a survey of high school learners in the Pretoria region. Unpublished Honours Dissertation. Pretoria: University of Pretoria.

4. Council on Higher Education. (2000). Size and Shape Task Team. Pretoria.

5. Cosser, M. and Du Toit, J. (2002). From school to higher education: Factors affecting the choice of grade 12 learners. South Africa, Cape Town: HSRC Publishers.

6. Haikins, F. (2006). Improving student acquisition activities. A study into how Cransfield University can better market its taught MSC programs to U.K nationals. M.Sc. Thesis, Cransfield School of management, United Kingdom.

7. Hardman, J. and Ng'ambi, D. (2003). A questionnaire environment for scaffolding learners questioning engagement with academic text: a university case study, South African journal of higher education, 17 (2), pp. 271-280.

8. Hawkins, D.I., Best, R.J. and Coney, K.A. (2004). Consumer behavior: building marketing strategy. $9^{\text {th }}$ ed. New York: McGraw-Hill.

9. Hoyt, J.F. and Brown, A.B. (2003). Identifying college choice factors to successfully market your institution, College and University, 78 (4), pp. 3-5.

10. Ivy, J. (2001). Higher education institution image: a correspondence analysis approach, The International journal of educational management, 15 (6), pp. 276-282.

11. Jones, M. (2002). The effectiveness of marketing communication strategies employed by universities and technikons in Cape Peninsula. M-Tech thesis, Peninsula Technikon, Cape Town.

12. Kotler, P. and Armstrong, G. (2013). Principles of Marketing: global and Southern African perspectives. Cape Town: Pearson Prentice Hall.

13. Martin, C.A. and Bush, A.J. (2000). Do role models influence teenagers' purchase intentions and behavior? Journal of consumer marketing, 17 (5), pp. 441-454.

14. Mills, M. (2004). Do and should financial aid packages affect students' college-choices? Journal of College Admission, Spring (183), pp. 28-29.

15. Petruzel, L. and Romannazzi, S. (2010). Educational value: how students choose university, International journal of educational management, 24 (2), pp. 139-158.

16. Pityana, B.N. (2004). Higher Education in South Africa: Future perspective. Key address at Boll Venter Literary Awards 2003, Johannesburg.

17. Redmond, P.H. (2010). The influence of marketing communication on students' decision to enrol at Durban university of Technology. Masters Dissertation. Durban University of Technology.

18. Sevier, R.A. (1993). Recruiting African-American undergraduates: a national survey of the factors that affecting institutional choice, Colleges and University, 68 (1), pp. 48-52.

19. South Africa, Department of Education. (1997). OBE in South Africa: background information for educators. Pretoria: Government Printers.

20. South Africa, Department of Education. (1998). Green paper for further education and training. Available at: http://www.polity.org.za/html/govdocs/greenpapers/furth. eredgp1.html. Accessed on 15 April 2015.

21. South Africa, Department of Education. (2001). National Plan on higher education in South Africa. Pretoria: Government Printers.

22. South Africa, Department of Education. (2002). Language policy for higher education. Pretoria: Government Printers.

23. South Africa, Department of Education. (2008). Higher education in context. Available at: http://www.ieasa.studysa.org/resources/study-sa/Facts-figures-section.pdf. Accessed on 10 August 2015.

24. Van der Merwe, I.J. (2004). The humanities in a changing SA: Challenges \& opportunities, South African Journal of Higher Education, 18 (1), pp. 127-139.

25. Wiese, M. (2008). A higher education marketing perspective on choice factors and information sources considered by South Africa's first year University students. Doctoral thesis, University of Pretoria.

Wiese, M., van Heerden, M., Jordaan, Y. and North, E. (2009). A marketing perspective on choice factors in selecting a higher education institution, South African Business Review, 13 (1), pp. 40-5 